\title{
Carbon stock, sequestration and soil properties among fields in smallholder farms in southern Ethiopia
}

Fanuel Laekemariam* (1)

\begin{abstract}
Background: Soil organic carbon (SOC) is key indicator of soil quality and health. It has substantial benefits to the ecosystem. Information on the magnitude of carbon pools under field scale of subsistence farms is scanty. This study aimed to assess carbon stock, sequestration and soil properties among different fields in smallholder farms of southern Ethiopia. Five field types within a farm were investigated viz. coffee (Coffea arabica L.), enset (Ensete ventricosum), root and tuber crop field (RTC), crop field used for growing cereals and pulses, and fallow land. For each field, eight representative fields as a replication were selected. Surface soil samples were collected, and analyzed to determine soil physico-chemical properties. In addition, $\mathrm{C}$ stock, C-sequestration, and $\mathrm{CO}_{2}$ emission were also evaluated.

Results: The result regarding soil properties revealed significant differences in almost all of investigated parameters. The minimum and maximum values being recorded were: bulk density (BD) $\left(1.05,1.29 \mathrm{gm} \mathrm{cm}^{-3}\right), \mathrm{pH}(6.1,7.0)$, SOC $(1.1,2.48 \%)$, TN (0.09-0.19\%), available P $(1.1,70.9 \mathrm{mg} / \mathrm{kg})$, total exchangeable bases $(9.5,20.5 \mathrm{Cmolc} / \mathrm{kg}), \mathrm{K} / \mathrm{Mg}$ (0.37,1.02), B (0.4, $1.2 \mathrm{mg} / \mathrm{kg}) \mathrm{Cu}(0.32,0.91 \mathrm{mg} / \mathrm{kg}), \mathrm{Zn}(5,20.5 \mathrm{mg} / \mathrm{kg}), \mathrm{Fe}(105.5,133.8 \mathrm{mg} / \mathrm{kg})$ and CEC $(18.6,27.5 \mathrm{mg} /$ $\mathrm{kg}$ ). Fields in the backyard (enset and coffee) showed lowest BD and maximum values of soil chemical properties. On contrary, highest BD and lowest values of chemical parameters were observed in crop and fallow fields. The result further indicated that the field that stocked and sequestered more carbon, and emitted less $\mathrm{CO}_{2}$ was coffee $>$ enset $>$ RTC > crop field > fallow land. C-stock and sequestration (t/ha) magnitude was being: coffee $(81.4,298.5)$, enset $(75.5,277.0)$, RTC $(68.8,252.6)$, crop field $(57.5,211.0)$ and fallow $(43.3,159)$. Using coffee field as least $\mathrm{CO}_{2}$ emitter and as the base value for comparison, the percentage increment in $\mathrm{CO}_{2}$ emission out of the sequestered carbon was 7.2\% (enset), 15.4\% (RTC), 29.3\% (crop field) and 46.7\% (fallow).Soil deterioration index (\%) relative to coffee field for OC, $N, P$, and $K$ in their order was as follows: enset $[-2.8,0,254.5,23.1]$, RTC $[-17.7,-31.6,-59.5,-34.6]$, crop field $[-35,-47.4,-79,-46]$ and fallow $[-55.7,-52.6,-94.5$, and -76.9$]$.

Conclusion: Different fields within smallholder farms exhibited significant variation in amount of carbon sequestered, $\mathrm{CO}_{2}$ emission, soil degradation and soil properties. Thus, climate smart soil management practices that would enhance carbon pool and simultaneously increasing soil quality are suggested e.g., integrated nutrient management.
\end{abstract}

Keywords: Carbon sequestration, Farm, Field, Soil nutrient, Soil degradation

*Correspondence: maedotmeklit@gmail.com Department of Plant Science, Wolaita Sodo University, Wolaita Sodo, Ethiopia

\section{Background}

Carbon dioxide $\left(\mathrm{CO}_{2}\right)$ is a major cause of the atmospheric greenhouse gases. Increasing concentration of $\mathrm{CO}_{2}$ into the atmosphere distorts the carbon $(\mathrm{C})$ cycle and influences the global climate, whereas sinking $\mathrm{CO}_{2}$ and increasing $\mathrm{C}$ stock of the ecosystem has positive effects (Melenya et al. 2015). Soil is the largest terrestrial 
sink of carbon (Melenya et al. 2015; Vagen and Winowiecki 2013). Sink of C from atmosphere to either plant into soil or from atmosphere into soil is called soil $\mathrm{C}$ sequestration.

Soil organic carbon (SOC) is key indicator of soil quality and health (Bhunia et al. 2018; Vagen and Winowiecki 2013). The benefits provided by SOC includes C storage, food and habitat for biodiversity, nutrient storage and supply, erosion control and increase buffering capacity, increasing soil infiltration rate and water holding capacity, and improving plant growth (Walcott et al. 2009). Thus, carbon sequestration in soil could be a 'win-win' situation, helping to reduce greenhouse gas levels in the atmosphere and improving soil quality for agricultural and forestry industries (Walcott et al. 2009). Meanwhile, agricultural practices can influence the $C$ balance through emission as well as sequestration (Tessema and Kibebew 2019).

In Ethiopia, agriculture is the dominant sector supporting the livelihood of majority of population that is growing at faster rate. It is entirely rain-fed and characterized by low input and low productivity (Eyasu et al. 2019). On contrary, farming size at the face of growing population is decreasing. There is also an expansion of agricultural areas in response to growing population and increasing demand for food (Teklu et al. 2020). It has been done at the expense of grazing and forest lands. Disturbance of soil ecosystems results in rapid depletion of SOC. This in turn results land degradation through deterioration of soil physicochemical properties (Tessema and Kibebew 2019) and finally results declining of crop production, and food security problems. These activities could have brought an increased interest in soil $\mathrm{C}$ sequestration and maintenance of soil ecosystem (Vagen and Winowiecki 2013).

Farmers in densely populated areas of Ethiopia own less land size. Particularly, in Wolaita, southern Ethiopia, farming has been taking place in less than a quarter of hectare (WZFEDD 2012). Like other parts in the country, farming is also entirely rain-fed and characterized by low input and low productivity (Fanuel and Kibebew 2020). To cope up the adverse effects of climate and secure household food demands, smallholder farmers divided the small size land into different fields and grow annual and perennial crops. Management practices applied to each field within a farm are variable. Difference in soil management practices influences soil $\mathrm{C}$ stock and soil quality (Tessema and Kibebew 2019). This subsequently depresses the efficiency of each field to functioning best and produce more yields.

Research findings in Ethiopia and elsewhere highlighted that the magnitude of soil $\mathrm{C}$ storage, carbon emission and soil quality responds strongly to aboveground landscape dynamics, including land-use change, soil management practices and land degradation processes (Tessema and Kibebew 2019; Bhunia et al. 2018; Manna et al. 2015; Melenya et al. 2015; Vagen and Winowiecki 2013). For instance, in Eastern Ethiopia at $20 \mathrm{~cm}$ depth $88.23 \mathrm{t} \mathrm{ha}^{-1}$ organic carbon could have been lost if forest land is converted into crop land (Tessema and Kibebew 2019). The same study further indicated higher $C$ stock in coffee agroforestry $\left(277.38 \pm 28.58 \mathrm{t} \mathrm{ha}^{-1}\right)$ than in cropland uses $\left(138.95 \pm 25.0 .1 \mathrm{t} \mathrm{ha}^{-1}\right)$.

While the effects of land use changes on $C$ stocks, $\mathrm{C}$ sequestration and soil properties have been widely studied, the mentioned information at field scale within a farm conditions are scanty. This would result limited utility of soil management recommendations as it does not address farm complexities. These gaps call the need to explore field scale variability of $C$ pools and soil properties to set recommendation on the maintenance and enhancement of SOC. Hence, this study aimed to assess $\mathrm{C}$ stock, sequestration and subsequent effects on soil properties among fields in the smallholder farms of southern Ethiopia.

\section{Materials and methods \\ Study area}

The study was conducted in small holder farmers' fields of two adjacent woredas (i.e. districts), Wolaita Zone, Southern Nations', Nationalities' and Peoples' Regional State (SNNPRS) of Ethiopia namely Damot Gale, and Sodo Zuria (Fig. 1). The woredas have potential for diverse agricultural activities (Fig. 1 and Table 1).The sites are located under mid highland (1500-2300 m.a.s.l) agroecological zone. Nitisol is the most prevalent soil type in the area. Agricultural activities are characterized by small-scale mixed subsistence farming system.

\section{Selection and surveying of farms}

Prior to sample collection different tasks were performed. Preliminary reconnaissance survey on the study site was conducted. It is noted that farmers in the area classify the farm into different fields (Table 1 and Fig. 2). This includes coffee (Coffea arabica L.)] based field; enset (Ensete ventricosum) based field; root and tuber field (RTC), and crop field that used to grow cereals and pulses viz tef (Eragrostis tef (Zucc.)Trotter), haricot bean (Phaseolus vulgaris L.), wheat (Triticum aestivum L.) and maize (Zea mays L). In addition, a crop field after long years of cultivation is being fallowed. Though rarely practiced in the area due to land shortage, it was also considered for evaluation.

Field survey was conducted and representative fields in the farm were randomly selected. For each field indicated in Table 1 and Fig. 2, four (4) representative replicates per 


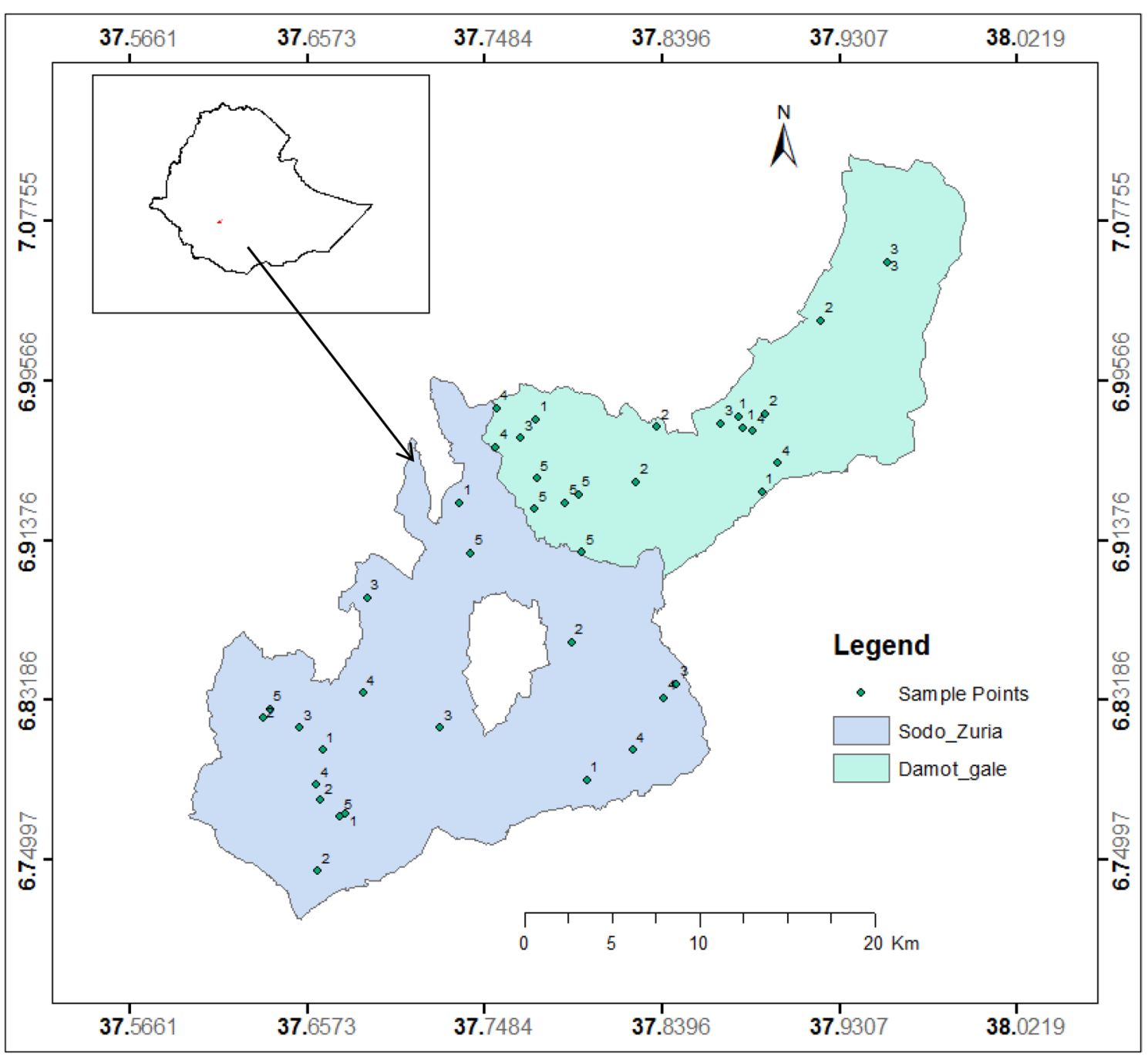

Fig. 1 Location map of Damote Gale and Sodo zuria districts of Wolaita zone, southern Ethiopia

Table 1 Characteristics of land use practices among fields in the farm

\begin{tabular}{|c|c|c|c|c|c|c|c|}
\hline \multirow[t]{2}{*}{ Field types } & \multirow[t]{2}{*}{ Location in the farm } & \multirow{2}{*}{$\begin{array}{l}\text { Crop intensity } \\
\text { (no. of crops/ } \\
\text { year) }\end{array}$} & \multirow[t]{2}{*}{ Residue management } & \multirow[t]{2}{*}{ Topography } & \multicolumn{3}{|c|}{ Fertilizer application } \\
\hline & & & & & $\mathrm{N}^{\mathrm{a}}$ (kg/ha) & $\mathrm{P}_{2} \mathrm{O}_{5}{ }^{\mathrm{a}}(\mathrm{kg} / \mathrm{ha})$ & FYM (t/ha) \\
\hline Coffee & Homestead & 1.5 & Retained & Gentle slope & - & - & 4.23 \\
\hline Enset & Homestead & 1.25 & Retained & Gentle slope & - & - & 3.50 \\
\hline RTC field & Middle field & 1.88 & Removed & Gentle slope & - & - & 3.51 \\
\hline Crop field & Out field & 2.00 & Removed & Gentle slope & 13.2 & 20.5 & - \\
\hline Fallow land & Out field & - & Free grazing & hilly slope & - & - & - \\
\hline
\end{tabular}

a Source of fertilizer is urea (46-0-0) and Di-ammonium Phosphate (18-46-0), respectively

woreda were identified. Then after, 20 fields per woreda and a total of 40 fields from the two woreda were surveyed. Similarity in terms of socio-economic status, elevation, slope, land scape position, soil management and land use history were considered during replicate field selections. Each field was georeferenced using a GPS. 


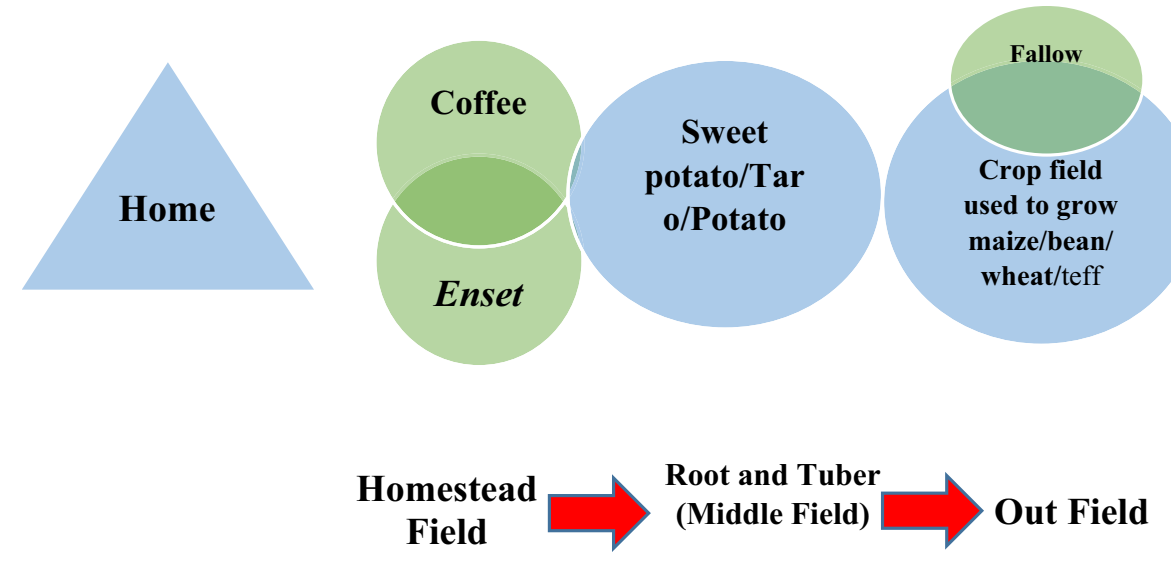

Fig. 2 Diagrammatic sketch of fields in the farm

\section{Soil sampling and laboratory analysis Soil sampling procedure}

From each field, 10-15 sub-samples from the surface were taken in zig zag pattern using soil auger to make a kilogram of composited sample. Each field was georeferenced using the Geographical Positioning System (GPS). In addition, relevant information such as coordinates, elevation, slope, topography, and soil management practices were also collected. After soil processing (drying, grinding and sieving), selected soil physicochemical properties were analyzed using standard laboratory analysis procedures.

Particle size distribution (PSD) was analyzed by laser diffraction method using laser scattering particle size distribution analyzer (Horiba- Partica LA-950V2). Soil bulk density (BD) was determined using the core method as described by Anderson and Ingram (1993). Soil pH (1:2 soil: water suspension) was measured with a glass electrode (model CP-501) (Mylavarapu 2009). Available phosphorous $(\mathrm{P})$, available sulfur $(\mathrm{S})$, exchangeable basic cations [calcium $(\mathrm{Ca})$, potassium $(\mathrm{K})$, and magnesium $(\mathrm{Mg})$, and extractable micronutrients (boron (B), copper $(\mathrm{Cu})$, iron $(\mathrm{Fe})$, manganese $(\mathrm{Mn})$ and zinc $(\mathrm{Zn}))$ were determined using Mehlich-III multi-nutrient extraction method (Mehlich 1984). The concentration of elements in the supernatant was measured using inductively coupled plasma (ICP) spectrometer.

Mid Infrared Diffuse Reflectance spectroscopy (MIR spectroscopy) was used to determine the amount of soil organic carbon (SOC), total nitrogen $(\mathrm{N})$ and cation exchange capacity (CEC). For MIR spectral analysis, soil samples weighing $0.035 \mathrm{~g}$ were loaded in a single well each in four consecutive wells of an aluminum microplate having 96 wells. The sample surface was gently pressed, leveled and smoothed using a micro-spatula (a rounded, smooth surface glass rod). The absorbance of diffused reflectance spectra was scanned using the HTSXT accessory of a Bruker-TENSOR 27 spectrometer. The background (i.e. soil sample free well) was scanned using roughened surface well of the aluminum microplate. Absorbance spectra of the entire soil samples were measured using OPUS version 7.0 software Bruker $^{\circledR}$ Optic $\mathrm{GmbH}, 2011$ ) with 32 scans and spectral range of 7400$600 \mathrm{~cm}^{-1}$ (wave numbers) including part of near infrared (NIR) region. The spectrum acquisition took an hour per plate. The MIR region spectra, in the wave number range of $4000-600 \mathrm{~cm}^{-1}(2500-16,667 \mathrm{\eta m})$ were used to predict soil properties. Quantitative analysis of the spectra was done using Quant 2 evaluation function of OPUS (software version 7) to predict concentration of SOC, TN and CEC. The average of four consecutive scans of each parameter was taken as a predicted data for the report. For the purpose of management, interpretation was given using proper ratings.

\section{Carbon and N Stocks, and C sequestration}

Stocks of soil organic carbon (SOC), stocks of nitrogen $(\mathrm{N})$ and carbon sequestration $\left(\mathrm{t} \mathrm{ha}^{-1}\right)$ were computed following the equation of Donovan (2013).

$$
\text { Soil C (or N) Stock }\left(\mathrm{t} \mathrm{ha}^{-1}\right)=\text { Soil OC (\%) or N (\%) } * \mathrm{BD}\left(\mathrm{kg} \mathrm{m}^{-3}\right) * \mathrm{~V} * 10^{-3}
$$


where BD: bulk density $\left(\mathrm{kg} \mathrm{m}^{-3}\right)$ and V: volume of the soil in cubic meter $=$ depth of soil $(\mathrm{m}) \times$ area of soil $\left(\mathrm{m}^{2}\right)$.

Carbon sequestration $\left(\mathrm{t} \mathrm{ha}^{-1}\right)$ refers to the amount of carbon stored in the form of $\mathrm{CO}_{2}$. It is obtained by multiplying SOC by 3.67 (i.e. the molecular mass of $\mathrm{CO}_{2} /$ atomic mass of $\mathrm{C}=44 / 12=3.67)$.

$$
\text { Carbon sequestration }\left(\mathrm{t} \mathrm{ha}^{-1}\right)=\mathrm{SOC}(\mathrm{t} \mathrm{C} / \mathrm{ha}) \times \mathrm{CO}_{2} / \mathrm{C}
$$

\section{$\mathrm{CO}_{2}$ emission}

To understand the $\mathrm{CO}_{2}$ balance of each field, net $\mathrm{CO}_{2}$ emissions $\left(\mathrm{t} \mathrm{ha}{ }^{-1}\right)$ were calculated from difference between reference field (RF) i.e., $\mathrm{C}$ sequestration $\left(\mathrm{t} \mathrm{ha}^{-1}\right)$ on field having maximum value minus sequestration in subsequent fields $\left(\mathrm{t} \mathrm{ha}^{-1}\right)$ (Eq. 3). The field that sinks more $\mathrm{C}$ was taken as reference value for comparison. performed. Data analysis was performed using Statistix 8 software.

\section{Resuts \\ Effects on selected soil physical properties}

Particle size distribution (PSD) among fields indicated non-significant difference and it showed moderate variability (Table 2). However, lower sand content was measured in soils of fallow land. Silt content showed decreasing trend from enset/coffee fields towards crop field (crop and fallow field). Furthermore, higher clay content was found on fallow land followed by crop field. As a result, enset and coffee fields have silty clay texture while other fields have clay texture (Table 2). Soil bulk density $(\mathrm{BD})$ significantly $(\mathrm{P}<0.05)$ differed among fields. Significantly smaller BD $\left(1.05 \mathrm{~g} \mathrm{~cm}^{-3}\right)$ was recorded from enset field, whilst higher $\mathrm{BD}$ value $\left(1.29 \mathrm{~g} \mathrm{~cm}^{-3}\right)$ was

$$
\mathrm{CO}_{2} \text { emission }\left(\mathrm{tha}^{-1}\right)=\mathrm{C} \text { sequestration }\left(\mathrm{tha}^{-1}\right) \text { on } \mathrm{RF}-\mathrm{C} \text { sequestration }\left(\mathrm{tha}^{-1}\right) \text { in other fields }
$$

where $\mathrm{RF}$ is a reference field that store (sequester) maximum carbon. With this assumption, $\% \mathrm{CO}_{2}$ emission was also computed from the ratio of $\left(\mathrm{CO}_{2}\right.$ emission/C sequestered)*100.

\section{Soil deterioration index among crop fields}

Soil deterioration index (DI) (\%) was calculated by adopting the approach indicated in Tessema and Kibebew (2019). It is assumed that the farm before conversion into coffee, enset, root and tuber, main field and fallow fields was similar in terms of SOC and other properties. Thus, the DI of SOC and macro nutrients (TN, available $\mathrm{P}$ and $\mathrm{K}$ ) under different fields was computed by comparing to reference field (Eq. 4). In addition, the change in SOC and TN were averaged to evaluate the magnitude of change on the two influential and interrelated properties (Tessema and Kibebew 2019).

$$
\mathrm{SDI}(\%)=\frac{\mathrm{PSF}-\mathrm{PRF}}{\mathrm{PRF}} \times 100
$$

where SDI is deterioration index, PSF is value of individual soil property $(\mathrm{P})$ under specific field $(\mathrm{SF})$ and PRF is mean value of individual soil property $(\mathrm{P})$ under reference field (RF). Note: Reference field refers to the mean of individual soil property (P) (e.g. SOC) on the field showing highest value.

\section{Data analysis}

One way analysis of variance (ANOVA) was employed to test significance variation among fields. In addition, Pearson correlation analysis on selected parameters was observed in the fallow field (Table 2).

\section{Effects on soil chemical properties}

Different fields in a farm have shown significant $(\mathrm{P}<0.05)$ differences in soil chemical properties except $\mathrm{S}$ and $\mathrm{Fe}$ (Table 2). In terms of soil reaction, enset, coffee and root and tuber fields (RTC) were categorized under neutral $\mathrm{pH}$ (6.6-7.3) while crop and fallow fields were found under moderately acidic (5.6-6.5) reaction as per the ratings of EthioSIS (2014). SOC and TN content showed declining trend from homestead to out fields. Coffee field had $125 \%$ and $54 \%$ higher OC compared to fallow and crop field, respectively. Enset, coffee and RTC fields were qualified under optimum OC [1.71-4.1\%] while crop field and fallow lands were categorized under low (1.2-1.7\%) and very low $(<1.2 \%)$, respectively (EthioSIS (2014)). Significantly $(\mathrm{P}<0.05)$ high TN content was found in soils under enset and coffee fields while the least was recorded on crop fields. TN was under optimum range $(0.15-0.3 \%)$ on enset and coffee fields. TN was low $(0.1-0.15 \%)$ on RTC and crop fields whereas it was very low $(<0.1)$ on fallow field (EthioSIS (2014)).

Investigated fields showed significant $(\mathrm{P}<0.05)$ differences in terms of available p. Available P ranged $(\mathrm{mg} /$ $\mathrm{kg}$ ) from 1.1 (fallow) to 70.9 (enset) fields. Exchangeable cations among fields were also significantly $(\mathrm{P}<0.05)$ different. The amount in all fields were in order of $\mathrm{Ca}^{2+}>\mathrm{Mg}^{2+}>\mathrm{K}^{+}$. The minimum and maximum $(\mathrm{cmol}$ $(+) / \mathrm{kg})$ in their order was: $\mathrm{Ca}(6.4-13.3), \mathrm{Mg}(1.8-$ 3.1) and $\mathrm{K}(0.6-3.2)$. The exchangeable bases among fields were in the order of: enset $>$ coffee $>$ RTC $>$ crop 
Table 2 Soil physical and chemical properties among fields in the farm

\begin{tabular}{|c|c|c|c|c|c|c|c|c|}
\hline \multirow[t]{2}{*}{ Parameters } & \multirow[t]{2}{*}{ Unit } & \multicolumn{5}{|c|}{ Field type } & \multirow[t]{2}{*}{ CV (\%) } & \multirow[t]{2}{*}{$\operatorname{LSD}_{0.05}$} \\
\hline & & Enset & Coffee & RTC & Crop field & Fallow & & \\
\hline Sand & $\%$ & 14 & 14 & 18 & 14 & 10 & 44.6 & ns \\
\hline Silt & $\%$ & 40 & 41 & 39 & 37 & 34 & 56.0 & ns \\
\hline Clay & $\%$ & 46 & 45 & 43 & 49 & 56 & 54.0 & ns \\
\hline Texture & & Silty Clay & Silty Clay & Clay & Clay & Clay & & \\
\hline $\mathrm{BD}$ & $\mathrm{g} \mathrm{cm}^{-3}$ & $1.05 c$ & $1.09 c$ & $1.12 \mathrm{bc}$ & $1.19 b$ & $1.29 a$ & 8.3 & 0.09 \\
\hline $\mathrm{pH}$ & - & $7.0 \mathrm{a}$ & $6.9 a$ & $6.7 a b$ & $6.3 \mathrm{bc}$ & $6.1 \mathrm{c}$ & 8.4 & 0.56 \\
\hline SOC & $\%$ & $2.41 \mathrm{ab}$ & $2.48 a$ & $2.04 b c$ & $1.61 \mathrm{c}$ & $1.10 \mathrm{~d}$ & 22.1 & 0.43 \\
\hline TN & $\%$ & $0.19 a$ & $0.19 a$ & $0.13 b$ & $0.10 \mathrm{~b}$ & $0.09 b$ & 0.04 & 34.5 \\
\hline AvP & $\mathrm{mg} / \mathrm{kg}$ & $70.9 a$ & $20.3 b$ & $8.1 \mathrm{~b}$ & $4.2 b$ & $1.1 \mathrm{~b}$ & 167.4 & 35.5 \\
\hline$A \vee S$ & $\mathrm{mg} / \mathrm{kg}$ & 11.1 & 11.2 & 10.0 & 9.2 & 9.3 & 29.9 & ns \\
\hline $\mathrm{Ca}$ & Cmolc/kg & $13.3 a$ & $10.4 b$ & $9.4 b$ & $8.1 b c$ & $6.4 c$ & 26.3 & 2.6 \\
\hline $\mathrm{Mg}$ & Cmolc/kg & $3.1 \mathrm{a}$ & $2.7 a$ & $2.1 \mathrm{~b}$ & $2.1 \mathrm{~b}$ & $1.8 \mathrm{~b}$ & 20.1 & 0.48 \\
\hline K & Cmolc/kg & $3.2 a$ & $2.6 a$ & $1.7 \mathrm{~b}$ & $1.4 \mathrm{~b}$ & $0.6 c$ & 29.0 & 0.56 \\
\hline $\mathrm{K}: \mathrm{Mg}$ & - & $1.02 \mathrm{a}$ & $0.96 a b$ & $0.84 b c$ & $0.70 c$ & $0.37 d$ & 22 & 0.17 \\
\hline C:N & - & $13.1 b$ & $13.1 b$ & $29.4 a$ & $16.5 a b$ & $12.4 b$ & 76.8 & 13.2 \\
\hline B & $\mathrm{mg} / \mathrm{kg}$ & $1.2 \mathrm{a}$ & $0.95 b$ & $0.56 c$ & $0.56 c$ & $0.4 c$ & 35.0 & 0.26 \\
\hline $\mathrm{Cu}$ & $\mathrm{mg} / \mathrm{kg}$ & $0.91 a$ & $0.66 \mathrm{~b}$ & $0.66 b$ & $0.45 b c$ & $0.32 c$ & 39.9 & 0.24 \\
\hline $\mathrm{Fe}$ & $\mathrm{mg} / \mathrm{kg}$ & 105.5 & 107.1 & 105.4 & 107.5 & 133.8 & 20.0 & ns \\
\hline $\mathrm{Mn}$ & $\mathrm{mg} / \mathrm{kg}$ & $213.25 a$ & 191.13ab & 180.37abc & $156.13 \mathrm{bc}$ & $131.63 c$ & 31.4 & 55.7 \\
\hline $\mathrm{Zn}$ & $\mathrm{mg} / \mathrm{kg}$ & $20.5 a$ & $13.4 \mathrm{~b}$ & $9.9 \mathrm{bc}$ & $8.0 \mathrm{~cd}$ & $5.0 \mathrm{~d}$ & 40.0 & 4.6 \\
\hline TEB & Cmolc/kg & $20.2 a$ & $16.5 b$ & $14.0 \mathrm{bc}$ & $12.4 \mathrm{~cd}$ & $9.5 d$ & 21.4 & 3.2 \\
\hline CEC & Cmolc/kg & $27.5 \mathrm{a}$ & $24.5 b$ & $21.8 b c$ & $21.0 \mathrm{~cd}$ & $18.6 d$ & 12.0 & 2.8 \\
\hline
\end{tabular}

ns not significant, $R T C$ root and tuber field

field $>$ fallow land. The proportion of $\mathrm{K}$ and $\mathrm{Mg}$ varied from 0.37 (fallow) to 1.02 (enset). Following the $\mathrm{K}$ and $\mathrm{Mg}$ threshold value of 0.7 adopted by Fanuel et al. (2018), the potential of Mg-induced K deficiency on crop field and fallow land was suspected. The result regarding micronutrients $(\mathrm{mg} / \mathrm{kg})$ such as $\mathrm{B}, \mathrm{Cu}, \mathrm{Mn}$ and $\mathrm{Zn}$ among fields were significant and their content ranged from: 0.4-1.2, 0.32 to $0.91,131.6-213.3,5.0$ to 20.5 , respectively. In all cases, the minimum and maximum value was recorded from fallow and enset fields, respectively. CEC showed decreasing trend from enset to fallow fields. Enset field showed high CEC (25-40 cmol (+)/kg) whereas, coffee, RTC and crop field recorded moderate CEC (15-25) CEC; and fallow lands qualified under low CEC $(<15$ $\mathrm{cmol}(+) \mathrm{kg})$.

\section{$\mathrm{C}$ and $\mathrm{N}$ stocks, $\mathrm{C}$ sequestration and $\mathrm{CO}_{2}$ emission}

Stocks of $\mathrm{C}$ and $\mathrm{N}$ in the fields and amount of $\mathrm{C}$ sequestered are presented in Table 3. Coffee field stored significantly highest $(\mathrm{P}<0.01)$ organic carbon and the lowest were recorded in the fallow land. However, coffee and enset fields were found statistically at par. C stock was

Table $3 \mathrm{~N}$ and C Stock, and C sequestered under fields in the farm

\begin{tabular}{|c|c|c|c|c|c|c|c|}
\hline & \multicolumn{5}{|c|}{ Field type } & \multirow[t]{2}{*}{$\mathrm{CV}(\%)$} & \multirow[t]{2}{*}{$\operatorname{LSD}_{0.05}$} \\
\hline & Enset & Coffee & RTC & Crop field & Fallow & & \\
\hline N stock (t/ha) & $6.0 \mathrm{a}$ & $6.3 a$ & $4.2 \mathrm{~b}$ & $3.6 b$ & $3.3 b$ & 36.3 & 1.73 \\
\hline $\mathrm{N}$ stock $\left(\mathrm{kg} / \mathrm{m}^{2}\right)$ & $0.6 a$ & $0.63 a$ & $0.42 b$ & $0.36 b$ & $0.33 b$ & 36.3 & 0.17 \\
\hline C stock (t/ha) & $75.5 \mathrm{a}$ & $81.4 a$ & $68.8 \mathrm{ab}$ & $57.5 b c$ & $43.3 c$ & 24.3 & 16.1 \\
\hline C stock $\left(\mathrm{kg} / \mathrm{m}^{2}\right)$ & $7.55 a$ & $8.13 a$ & $6.88 a b$ & $5.75 b c$ & $4.33 c$ & 24.3 & 1.61 \\
\hline C sequestered (t/ha) & $277.0 \mathrm{a}$ & $298.5 a$ & $252.6 a b$ & $211.0 \mathrm{bc}$ & $159.0 \mathrm{c}$ & 24.3 & 59.0 \\
\hline $\mathrm{C}$ sequestered $\left(\mathrm{kg} / \mathrm{m}^{2}\right)$ & $27.7 a$ & $29.85 a$ & $25.26 a b$ & $21.1 b c$ & $15.9 c$ & 24.3 & 5.9 \\
\hline
\end{tabular}


in the order of coffee $>$ enset $>$ RTC $>$ crop field $>$ fallow land implying that it decreases towards the out fields. $\mathrm{N}$ stock was significantly $(\mathrm{P}<0.05)$ varying among fields and showed moderate variability. It was in the order of coffee $>$ enset $>$ RTC $>$ crop field $>$ fallow land. Yet, N stock at coffee field was statistically at par with enset field. Generally, fields close to home accumulated $30-50 \%$ more $\mathrm{N}$ than middle and out fields.

Significant variation $(\mathrm{P}<0.05)$ among fields in $\mathrm{C}$ sequestration was observed. It followed the trend of $\mathrm{C}$ stock. This signifies that coffee and enset fields have stored better amount of $\mathrm{C}$ than fallow and crop fields as a result they reduced $\mathrm{CO}_{2}$ emission into the atmosphere. The $\mathrm{CO}_{2}$ emission (amount and percentage) relative to coffee field ranged from $21.5 \mathrm{t} / \mathrm{ha}$ (7.2\%) (enset field) to $159.0 \mathrm{t} / \mathrm{ha}(46.7 \%)$ on fallow land (Table 4). It was also noted the magnitude of $\mathrm{C}$ sequestration in coffee field was relatively superior to enset field.

\section{Soil deterioration index among crop fields}

Soil deterioration index (DI) (\%) relative to coffee field for $\mathrm{OC}, \mathrm{N}, \mathrm{P}$, and $\mathrm{K}$ in their order was: enset $[-2.8,0$, 254.5, 23.1], RTC [-17.7, - 31.6, - 59.5, -34.6], crop field $[-35,-47.4,-79,-46]$ and fallow $[-55.7,-52.6$, -94.5 , and -76.9 ] (Figs. 3, 4).The average DI value of TN and SOC was: $1.7 \%$ (enset), 26.03\% (RTC), 40.9 (crop field), $55.4 \%$ (fallow field) (Fig. 4). In all cases, the magnitude of soil degradation is increasing towards the fallow field.

\section{Discussion}

\section{Field management}

Though the average land holding size is very small, small holder farmers in the study area is sub-divided the farm into different fields and used to manage enset, coffee, RTC and crop field. The fields are intensively cultivated and the spaces available under each field are utilized via intercropping (Table 1). Soil management practices were found field specific. For instance, enset, coffee, and RTC fields are exclusively managed with farm yard manure

\begin{tabular}{llll}
$\begin{array}{l}\text { Table } 4 \mathbf{C O}_{\mathbf{2}} \\
\text { as compared to coffee field }\end{array}$ & fields in the farm \\
\hline Field type & $\begin{array}{l}\text { C sequestered (t/ } \\
\text { ha) }\end{array}$ & $\begin{array}{l}\mathbf{C O}_{\mathbf{2}} \text { emission } \\
\text { (t/ha) }\end{array}$ & $\begin{array}{l}\mathbf{C O}_{\mathbf{2}} \\
\text { emission } \\
\mathbf{( \% )}\end{array}$ \\
\hline Coffee & 298.5 & - & - \\
Enset & 277.0 & 21.5 & 7.2 \\
RTC & 252.6 & 45.9 & 15.4 \\
Crop field & 211.0 & 87.5 & 29.3 \\
Fallow & 159.0 & 139.5 & 46.7 \\
\hline
\end{tabular}

(FYM) and house wastes. The amount of organic inputs applied was in the order of coffee > enset $>$ RTC fields. Organic inputs can build soil organic matter (OM), restores the plant nutrient into the soil system, and attaches soil particles and protect from erosion (Walcott et al. 2009). On the other hand, fields that belong to cereal and pulses are managed with inorganic fertilizer. However, the amount used by each field was inadequate to replenish the soil quality (Table 1 ). This may cause the depletion of soil organic matter and essential nutrients to extent limiting crop yield (Eyasu et al. 2019; Fanuel and Kibebew 2020).

\section{Soil properties}

Differences in particle size distribution and soil texture among fields was probably attributed to the prevalence of water erosion on the crop and fallow field than other fields (Fanuel et al. 2016). On fields covered with perennial crops (enset and coffee), soil particles are less likely detached with erosion and impacts of rain droplets. This is probably due to higher SOC and better canopy cover. Comparatively, lower SOC on crop and fallow fields would make the soils susceptible to erosion and made them to have high clay content and clay texture. Tessema and Kibebew (2019) also reported the higher clay content at the surface of cultivated lands. They pointed out that the selective removal of the finer particles, such as silt and clay, by water erosion from the natural forest and their subsequent accumulation on cultivated lands caused the higher clay content.

The lower soil bulk density (BD) on enset field and higher $\mathrm{BD}$ value on out-fields could be linked with the presence of higher and lower soil OM accumulation, respectively (Oguike and Mbagwu 2009). This is also justified with significantly $(\mathrm{P}<0.001)$ inverse relationship between organic matter and $\mathrm{BD}(\mathrm{r}=-0.5)$. The soil $\mathrm{BD}$ values in all fields were within the favorable range (Hazelton and Murphy 2007). Thus, restriction of plant growth as consequence of excessive compaction is less likely to occur.

Farmers apply home left wastes particularly wood ash into enset and coffee fields. This is why these fields had neutral soil $\mathrm{pH}$ than main/fallow field that was not getting same treatment (Lalisa et al. 2010). Pearson correlation matrix also indicated that $\mathrm{pH}$ was significantly $(\mathrm{P} \leq 0.001)$ correlated with amount of clay $(\mathrm{r}=-0.36)$, available $P(r=0.55)$, total exchangeable bases $(r=71)$, and CEC $(r=0.64)$. Overall, the acidic soil reaction in out-fields could be due to leaching, depletion of basic cations through crop harvest and continuous use of acid-forming fertilizers, such as urea and di-ammonium phosphate $\left.\left(\mathrm{NH}_{4}\right)_{2} \mathrm{HPO}_{4}\right)$ (Table 1) (Yihenew et al. 2015; Alexandra et al. 2013). 
DI-C(\%) among fields in the farm

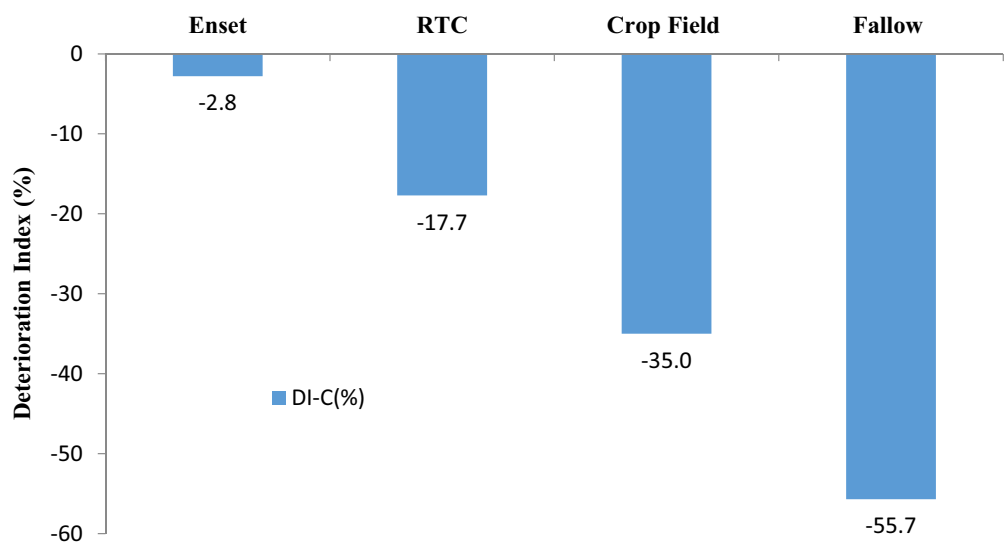

DI-N (\%) among crop fields in the farm

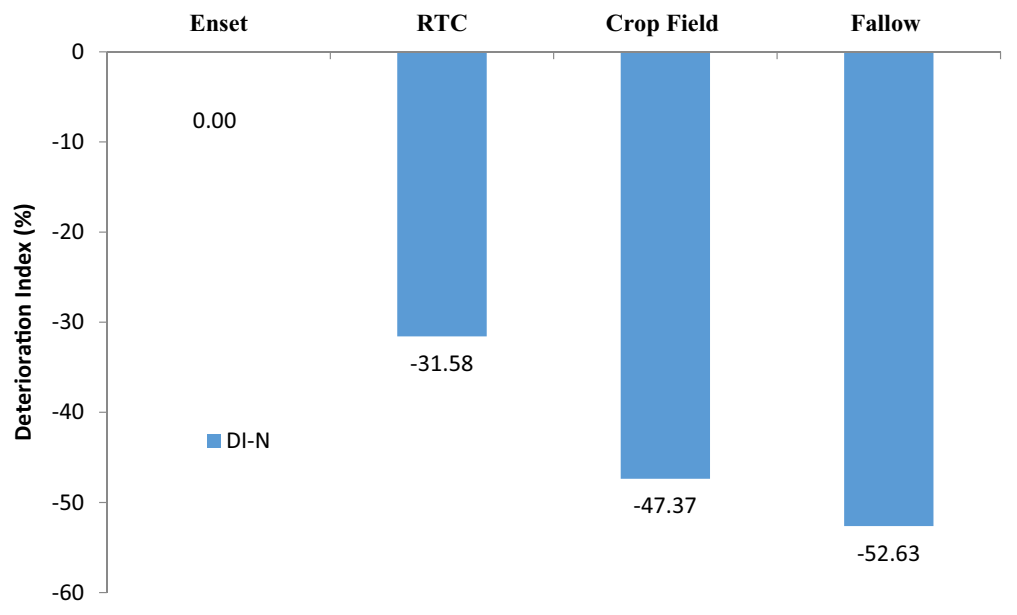

DI Average ( $\mathrm{C}$ and $\mathrm{N}$ ) among fields in the farm

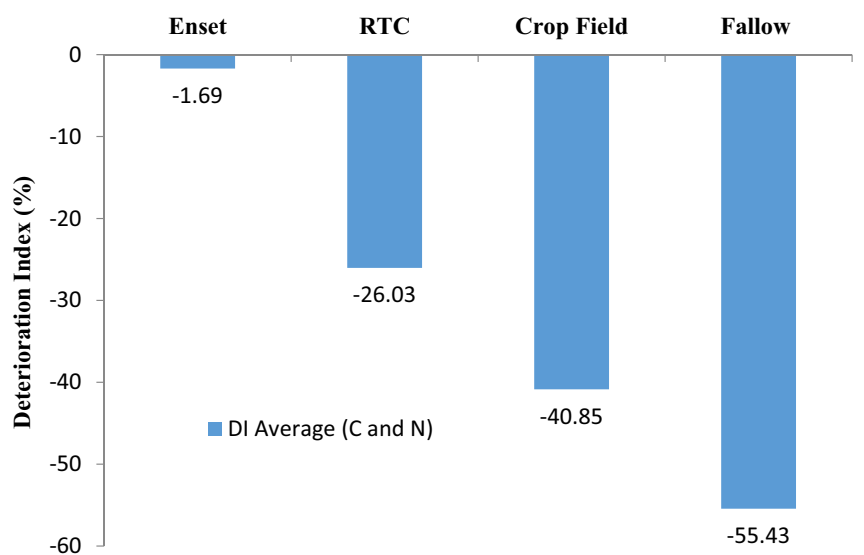

Fig. 3 Deterioration index (DI) (\%) of C, N and their average on among fields in the farm 


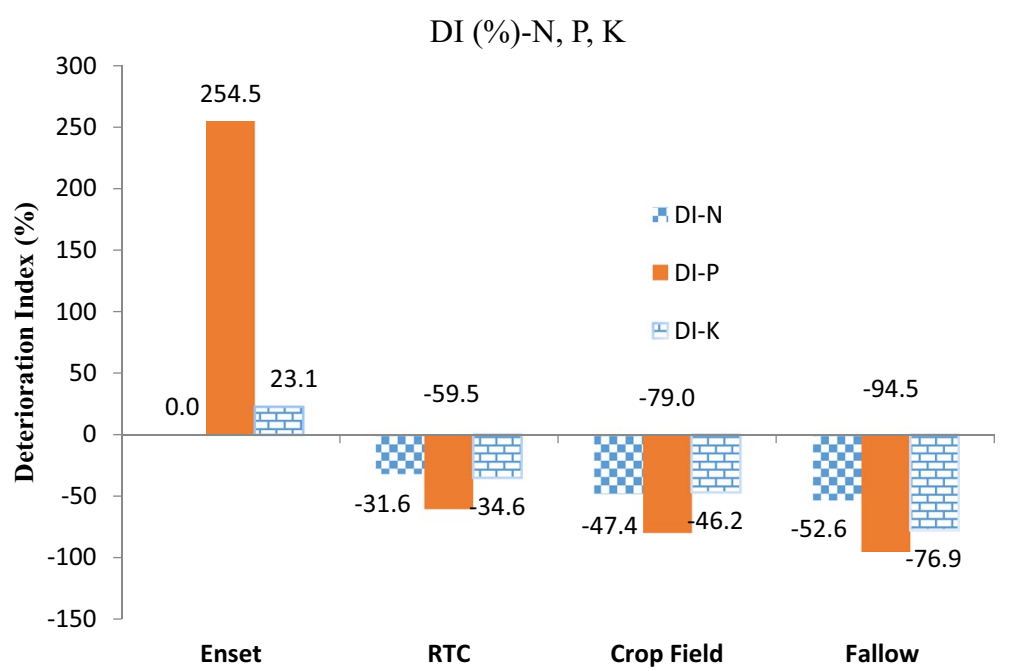

Fig. 4 Deterioration index (DI) (\%) of macro nutrients (N, P and K) on different fields

Likewise, other soil chemical properties have also shown significant differences. This is illustrating the widely contrasting SOC and nutrient dynamics among investigated fields. Noticeable gradient from enset towards out-fields was observed. The higher total $\mathrm{N}$ under enset/coffee field could be attributed to higher SOC content, which is the major source of total N (essentially organic nitrogen). This is best described by highly significant $(\mathrm{P} \leq 0.001)$ and positive correlation between $\mathrm{TN}$ and $\mathrm{OC}(\mathrm{r}=0.98)$. Farmers relatively retain more residues under enset and coffee fields. The continuous decomposition of organic materials supplied over a period of time and the lesser occurrence of soil erosion due to particle aggregation on enset/coffee fields might be attributed to higher level of $\mathrm{p}$, total exchangeable bases, soil micronutrients and CEC (Walcott et al. 2009). Furthermore, the application of home left wastes particularly wood ash into coffee and enset fields might result the high exchangeable bases. Pitman (2006) reported that wood ash provides considerable amount of $\mathrm{Ca}, \mathrm{Mg}, \mathrm{K}$ and other trace elements. The higher exchangeable bases on backyard fields is due to the effect of external inputs (wood ash, and household and animal wastes) because of its proximity to living quarters was also reported by Lalisa et al. (2010).

The lower nutrient values in RTC, crop and fallow fields might be due to non-use of mineral fertilizers containing $\mathrm{S}, \mathrm{K}$ and micro nutrients, and continuous crop uptake without compensation. In addition, the practice of complete residue removal degrades the SOC and soil quality of the crop fields. According to Fanuel et al. (2016) farmers in the area do not deliberately practice fallowing; rather they practiced when the cultivable land has reached to the point of no return. Thus, SOC and nutrient content under fallow field becomes very poor. The recovery process demands more time soil.

\section{Soil C stock, $\mathrm{C}$ sequestration and $\mathrm{CO}_{2}$ emission}

Enset and coffee fields relatively were found the most sustainable and less degradable fields in terms of SOC and $\mathrm{C}$ sequestered followed by RTC fields $>$ crop field $>$ fallow land. The higher $\mathrm{C}$ stock and sequestration in the enset/ coffee fields could be attributed to the relatively higher application rates of organic inputs than other fields (Table 1). The low SOC stocks in crop and fallow fields are possibly due to continuous cultivation and complete residue removal. The prevalence of erosion in crop and fallow fields may result in low SOC stock (Vagen and Winowiecki 2013).

Comparatively, the highest carbon stock and sequestration on coffee than enset fields is also ascribed to the long years of accumulation. Coffee plants stay for longer years in the field than enset plant. For this reason, continuous decomposition of the accumulated organic inputs and the litter under coffee fields could result highest carbon stock and sequestration. Nevertheless, soil management practices at coffee and enset fields such as maintaining crop residue application, applying FYM and home left residues could play an important role in the maintenance of SOC levels, soil quality and productivity. The implication is that the more stocks of $\mathrm{C}$, the lesser $\mathrm{CO}_{2}$ emitted into the atmosphere. According to Melenya et al. (2015) applying of organic inputs like mulching increases recycling of nutrients and minerals, fertilizer use efficiency, improves soil chemical and physical properties and, decreases soil erosion. 
Soil under the crop field and fallow land recorded lower carbon pool and higher $\mathrm{CO}_{2}$ emission than enset/coffee based complexities. According to Melenya et al. (2015), soil degradation processes as well as rapid decomposition of organic matter in cultivated soils were the major cause for the release of $\mathrm{CO}_{2}$ from the system as the land use systems that added more residues recorded less emission of $\mathrm{CO}_{2}$. The present result also corroborated with previous studies by Bhunia et al. (2018) who reported significantly lower storage capacity of carbon in the fallow land.

Soil carbon stock $\left(\mathrm{t} \mathrm{ha}^{-1}\right)$ at $0-20 \mathrm{~cm}$ under different land uses in eastern Ethiopia by Tessema and Kibebew (2019) indicated the following amount: natural forest $(141.34 \pm 12.32)$, coffee agroforestry $(93.78 \pm 6.92 \mathrm{t} / \mathrm{ha})$, grazing land $(57.38 \pm 10.29)$ and crop land $(53.11 \pm 8.42)$. In the present study, the amount in coffee (54.23 t/ha) and crop $\left(38.33 \mathrm{t} \mathrm{ha}^{-1}\right)$ fields at $0-20 \mathrm{~cm}$ depth were less compared to the study in Ethiopian coffee-agroforestry and crop land uses, respectively (Tessema and Kibebew 2019). This signifies that farming practices are very exploitive. Furthermore, the loss of organic carbon is likely to increase $\mathrm{CO}_{2}$ emission from the soil system. Therefore, implementing climate smart field management practices that fit to subsistence farming condition but having a capacity to enhance SOC pool, restore soil quality and minimize emission has to be put in place. Amongst them conservation tillage, integrated nutrient management, agro-forestry, intercropping and green manuring are suggested (Manna et al. 2015; Melenya et al. 2015; Jarecki and Lal 2003).

\section{Soil deterioration index among fields}

Comparing different fields, the higher DI in the crop and fallow fields could be associated with inadequate soil management practices. Fanuel et al. (2016) indicated that smallholder farmers in the study area apply few/no organic inputs, completely remove of crop residues and practice more intensive cultivation. The inputs applied could not compensate the mineralization of $\mathrm{OM}$ and $\mathrm{N}$ losses and accelerate the oxidation rate of soil $\mathrm{OM}$ (Girma and Endalkachew 2013). The finding of Tessema and Kibebew (2019) in Ethiopia also indicated a high and low deterioration index under cultivated lands and coffee agroforestry, respectively. The authors explained that highly exploitative farming practices on crop land attributed to the net degradation of OC and TN. Nonetheless, organic inputs applied to coffee $\left(4.23 \mathrm{t} \mathrm{ha}^{-1}\right)$ and enset $\left(3.5 \mathrm{t} \mathrm{ha}^{-1}\right)$ fields are below the required amount (Table 1). As an example, amount applied on enset field are very far from 10 to $20 \mathrm{tha}^{-1}$ which is the amount suggested for better growth and yield of enset (Mulugeta and Admasu 2012). Thus, soil management practices that maintain and enhance the carbon pool are suggested.

\section{Conclusion}

The result among fields in the farm illustrates significant differences in soil physio-chemical properties, C stocks and sequestration. Noticeable gradients on measured parameters were formed. The gradient from better to worse direction was towards enset/coffee $\rightarrow$ root and tuber field $\rightarrow$ crop field $\rightarrow$ fallow field. Overall, variation in soil management practices at field level was the driving factor resulting differences in carbon stock and soil quality. Finally, the detected gradient calls for field specific management recommendation.

In conclusion, on out fields implementing climate smart field management practices that would enhance SOC pool, restore soil quality and minimize emission has to be put in place. This may include conservation tillage, integrated nutrient management, agro-forestry, maintaining/incorporation of crop residues, and green manuring. In order to reduce the prevalence of erosion and also obtain feed for livestock's, integrated soil and water conservation practices have to be promoted. Although back yard and middle fields in the farm were comparatively better, soil management was not adequate. Thus, integrated use of organic and mineral fertilizers is suggested.

\section{Abbreviations \\ BD: soil bulk density; DI: soil degradation index; SOC: soil organic carbon; PSD: soil particle size distribution.}

\section{Acknowledgements}

The author wishes to thank keen and cooperative farmers of Wolaita who shared their experience and worked with researcher.

\section{Authors' contributions}

FL collected, analyzed, interpreted and prepared the manuscript. The author read and approved the final manuscript.

\section{Funding}

This study was made possible by a research grant from Agricultural Transformation Agency (ATA) in Ethiopia under EthioSIS project.

\section{Availability of data and materials}

I declare that the data and materials presented in this manuscript can be made available as per the editorial policy of the journal.

Ethics approval and consent to participate

Not applicable to this manuscript.

Consent for publication

All data and information are generated and organized by the authors.

Competing interests

The author declares that there is no competing interest.

Received: 1 April 2020 Accepted: 13 July 2020

Published online: 26 July 2020

\section{References \\ Alexandra M, Charles R, Jeangros B, Sinaj S (2013) Effect of organic fertilizers and reduced-tillage on soil properties, crop nitrogen response and crop}


yield: results of a 12-year experiment in Changins, Switzerland. Soil Tillage Res 126:11-18

Anderson JM, Ingram JSI (1993) Tropical soil biology and fertility: a handbook of methods, 2nd edn. CAB International, Wallingford, UK

Bhunia GS, Shit PK, Maiti R (2018) Comparison of GIS-based interpolation methods for spatial distribution of soil organic carbon (SOC). J Saudi Soc Agric Sci 17:114-126

Bruker Optic GMbH (2011) Opus Release 7 [software]. Ettlingen, Germany Donovan P (2013) Measuring soil carbon change: a flexible, practical, local method. pp 1-56

EthioSIS (Ethiopia Soil Information System) (2014) Soil fertility status and fertilizer recommendation atlas for Tigray regional state, Ethiopia. Addis Ababa, Ethiopia

Eyasu E, Okoth PF, Smaling EMA (2019) Explaining bread wheat (Triticum aestivum) yield differences by soil properties and fertilizer rates in the highlands of Ethiopia. Geoderma 339:126-133. https://doi.org/10.1016/j. geoderma.2018.12.020

Fanuel L, Kibebew K (2020) Explaining soil fertility heterogeneity in smallholder farms of southern Ethiopia. Appl Environ Soil Sci. https://doi. org/10.1155/2020/6161059

Fanuel L, Kibebew K, Tekalign M, Erik K, Heluf G (2016) Physiographic characteristics of agricultural lands and farmers' soil fertility management practices in Wolaita zone, Southern Ethiopia. Environ Syst Res 5(24):1-16. https://doi.org/10.1186/s40068-016-0076-z

Fanuel L, Kibebew K, Hailu S (2018) Potassium (K) to Magnesium (Mg) ratio, its spatial variability and implications to potential Mg-Induced K Deficiency in Nitisols of Southern Ethiopia. Agric Food Security 7:13. https://doi. org/10.1186/s40066-018-0165-5

Girma A, Endalkachew W-M (2013) Soil properties, and soil organic carbon stocks of tropical Andosol under different land uses. Open I Soil Sci 3:153-162

Hazelton P, Murphy B (2007) Interpreting soil test results. What do all the numbers mean?. CSIRO Publishing, Australia

Jarecki MK, Lal R (2003) Crop management for soil carbon sequestration. Crit Rev Plant Sci 22(5):471-502. https://doi.org/10.1080/07352680390253179

Lalisa A, Hager H, Sieghardt M (2010) Effects of land use types on soil chemical properties in smallholder farmers of central highland Ethiopia. Ekologia (Bratislava) 29(1):1-14

Manna MC, Subba Rao A, Mandal A (2015) Impact of agricultural land management practices on soil carbon sequestration. Indian J Soil Conserv 43(3):204-212
Mehlich A (1984) Mehlich III soil test extractant: a modification of Mehlich II extractant. Commun Soil Sci Plant Anal 15:1409-1416

Melenya C, Bonsu M, Logah V, Quansah C, Adjei-Gyapong T, Yeboah IB, Tuffour HO, Abubakari A (2015) Carbon sequestration in soils under different land use systems and it impact on climate change. Appl Res J 1(3):164-168

Mulugeta D, Admasu T (2012) Research and development experience on Enset agronomy. In: Mohammed Y, Tariku H, eds. Enset research and development experiences in Ethiopia. Proceedings of Enset National Workshop, 19-20 August 2010, Wolkite, pp. 48-63

Mylavarapu R (2009) UF/IFAS extension soil testing laboratory (ESTL) analytical procedures and training manual

Oguike PC, Mbagwu JSC (2009) Variations in some physical properties and organic matter content of soils of coastal plain sand under different land use types. World J Agric Sci 5(1):63-69

Pitman MR (2006) Wood ash use in forestry - a review of the environmental impacts. Forestry 79(5):563-588

Teklu E, Williams TO, Fanuel L (2020) Restoration of grazing land to increase biomass production and improve soil properties in the Blue Nile basin: effects of infiltration trenches and Chloris Gayana reseeding. Renewable Agric Food Syst. https://doi.org/10.1017/S1742170519000425

Tessema T, Kibebew K (2019) Carbon stock under major land use/land cover types of Hades sub-watershed, eastern Ethiopia. Carbon Balance Manage 14:7. https://doi.org/10.1186/s13021-019-0122-z

Vagen TG, Winowiecki LA (2013) Mapping of soil organic carbon stocks for spatially explicit assessments of climate change mitigation potential. Environ Res Lett 8(2013):015011

Walcott J, Bruce S, Sims J (2009) Soil carbon for carbon sequestration and trading: a review of issues for agriculture and forestry. Bureau of Rural Sciences, Department of Agriculture, Fisheries \& Forestry, Canberra

WZFEDD (Wolaita Zone Finance and Economic Development Department) (2012) Wolaita Zone Socio-Economic information. Wolaita Sodo, Ethiopia

Yihenew G, Fentanesh A, Addisu Solomon (2015) The effects of land use types, management practices and slope classes on selected soil physico-chemical properties in Zikre watershed, North-Western Ethiopia. J Environ Syst Res 4(3): 1-7

\section{Publisher's Note}

Springer Nature remains neutral with regard to jurisdictional claims in published maps and institutional affiliations.

\section{Submit your manuscript to a SpringerOpen ${ }^{\circ}$ journal and benefit from:}

- Convenient online submission

- Rigorous peer review

- Open access: articles freely available online

- High visibility within the field

- Retaining the copyright to your article

Submit your next manuscript at $\boldsymbol{\nabla}$ springeropen.com 